\title{
Avrupamerkezcilik ve Türk Tarih Tezi
}

\author{
Ali Satan*
}

1990'larda Londra'da karşılaştığım Pakistanlı gençler, Türk olduğumu öğrenince evlerine davet ettiler. Evlerinde yaptığımız tarih sohbetinde, "Osmanlı Devletinin hilafet devleti olduğunu, emperyalizm yapmadığı için imparatorluk denmemesi gerektiğini, kendilerinin Pakistanlı olarak emperyalizmin ne demek olduğunu yaşayarak öğrendiklerini" söyledikten sonra şu çarpıcı tespitte bulunmuşlardı: "Bugünümüze hâkim olan Batılılar tarihimize de hâkim olmak istiyorlar. Bunu da tarihimizi Batılıların gözleri ile görmemizle, Batılıların kavramlarıly açıklamamızla sağlıyorlar."

Hayatın her alanında Avrupa medeniyetinin üstünlüğünü vurgulayan bir düşünce tarzı olarak tanımlanan Avrupamerkezcilik, özellikle bilim, felsefe, sanat vs. çalışmalarında Avrupa düşüncesi ve medeniyetinin Avrupa dışı tüm medeniyetlerden üstünlüğü tezini açıktan ya da gizli savunan bir yaklaşım olarak tanımlanmaktadır (Şimşek, 2007, s. 16-17) ${ }^{1}$

Avrupamerkezci tarih yazıcılığı ciddi eleştiriler almış ve almaktadır. ${ }^{2}$ 1999'da Norveç/ Oslo'da yapılan Tarihin Kötüye Kullanma Biçimi ile Yüzleşmek sempozyumunun açış

* Doç. Dr., Marmara Üniversitesi, Fen Edebiyat Fakültesi, Tarih Bölümü.

İletişim: satanali@hotmail.com. Marmara Üniversitesi, Fen Edebiyat Fakültesi, Tarih Bölümü, Göztepe Kampüsü 34722, Kadıköy, İstanbul.

1 Avrupamerkezciliğin deneysel bir inançlar dizisi olduğuna dair bk. Blaut, (2012, s. 26 vd.).

2 Jack Goody, tarihyazımı aracılığıyla tarihin Batı tarafından ele geçirildiğini bunun da geçmişin Avrupa, çoğu zaman da Batı Avrupa ölçeğinde olan bitenlere göre kavramsallaştırılıp sunulmasını, ardından da dünyanın geri kalanına dayatıldığını belirterek bunu Tarih Hırsızlığı olarak nitelemektedir. Goody, Avrupamerkezci tarihyazımının Avrupa'yı, demokrasi, merkantilizm, kapitalizm, özgürlük, bireycilik gibi değer yüklü bir kurumlar silsilesini icat ettiği konusunda çok iddialı bulur ve bu kurumlar geniş bir dizi insan topluluğunda da mevcut olmasına rağmen görmezden gelindiğini ileri sürer bk. Goody, (2012, s. 1). Clive Ponting de şimdiye kadar dünya tarihinin ele alınma yönteminin çok kusurlu ve tarafgir olduğunu; en temel hatanın ise; "Batı Uygarlığı"nın dünya tarihindeki temel dinamik güç ve insan toplulukları ve düşünce biçimlerinin parçası olan iyi ve ilerici ne varsa hepsinin örneği olduğu inancıyla bütünleşen köklü bir Avrupamerkezcilikten" kaynaklandığını vurgular. Bu tür bir bakış açısının diğer gelenek ve toplulukların hem rolünü hem de önemini, ayrıca dünyadaki insanların büyük çoğunluğunun deneyimlerinin değerini önemsemeyeceği ya da görmezden geleceği ortadadır." diye yazmaktadır bk. Ponting, $(2012$, s. 1). Ayrıca bu konuda şu iki makaleye de bakılabilir: Beritan \& Şimşek, (2011, s. 301-314); Çırakman, (2001, s. 28-52). 
konuşmasını yapan Gerog Iggers tarafından; 19. yüzyıl yazarlarının Batı uygarlığının üstünlüğünün altını çizmeleri, etnik merkezci görüş olarak nitelendirildi ve bağrında sömürgeci tutumların ve ırkçılığın ilk belirtilerinin yer aldığına işaret edildi (Iggers, 2003) "20. Yüzyılda Tarih Yazımı" Tarihin Kötüye Kullanımı içinde (Çev. Nurettin Elhüseyni) İstanbul: Tarih Vakfı Yayınları, s. 3).

Georg Iggres'in belirttiği üzere Avrupamerkezci görüşün, Avrupa sömürgeciliği ile arasında önemli ve yıkıcı bir paralellik vardı. Âdeta madalyonun iki yüzü olarak da tavsif etmemiz mümkün olan Avrupamerkezciliğin, İslam ve Türk tarihine yaklaşımını Halil Berktay şöyle özetlemektedir:

"19. yüzyılda emperyalist Batı́nın oryantalizmi "Euro-centrism" (Avrupamerkezcilik) ile esaslı maluldü. Bu yaklaşım, "hasta adam" Türkiye ile birlikte Türklerin tarihini de sömürgeleştirmeye yönelikti. Oryantalizm, bir bütün olarak İslam tarihine "binbirgece masalı" havasında bakıyor, onu belli belirsiz bir nostaljinin konusu, egzotik (yabancıl), olağanüstü ve çağdışı bir olay olarak görüyordu. İslamiyet öncesinde ve İslam tarihi içinde Türklerin özel tarihi pek az biliniyordu. 20. yüzyıl başı oryantalizminin bir dalı durumundaki Türkolojiye göre, 11. yüzyılda İslam uygarlığı alanına girmelerinden önce Türkler her türlü uygarlık başlangıcından yoksun, sadece savaşçı ve yıkııı bir güç idiler. Bu fatihler, Bağdat'ı almalarından sonra ortaya çıkan Türk-i̇slam devletlerine kendilerinden hiçbir şey katmamışlardı: Söz konusu siyasi kuruluşlar, uygarlık namına gerçekleştirdikleri her şeyi, İran-İslam geleneğine borçluydular. Bu kadar geri, tipik hayati faaliyeti bu denli yağma savaşşılığından ibaret bir kavim, Osmanlı İmparatorluğunu da zapt ettiği yerlerin Müslüman olmayan nüfusundan yararlanarak ve bütünüyle Bizans kurumlarını taklit yoluyla kurmuş olmalıydı. Türklerin Bizans ile temas öncesinde mutlak bir gerilik içinde bulundukları fikri, böylece, Osmanlı devleti ve uygarlığının Bizans'ın halefi olduğu fikriyle örtüşüyordu... Oryantalizm, dört yüz yıl boyunca Batı́nın Osmanlı yayılmacılığı tehdidi altında yaşamış olmasının intikamını, şimdi Batı hegemonyası döneminde, Türklerin Avrupa'dan sürülmeye, hatta Anadolu'da dahi başkalarınca yönetilmeye müstahak oldukları anlamına gelen zit bir teoriyle alıyordu." (Berktay, 2002, s. 38).

Avrupamerkezci tarih anlayışı, Avrupa sömürgeciliğinin meşrulaştırılması idi. Nihayet I. Dünya Harbi ile başlayan yeni işgaller de aynı zihniyet tarafından meşru, makul ve hatta gerekli olarak görülüyordu. Paris Barış Konferansı'nda Yeni Dünya Düzeni bu felsefi arka plan ile çiziliyordu. Ancak, Türklerin, İstiklal Harbi'ni kazanmaları ile küresel ölçekte olmasa da bölgesel bağlamda hesapların revize edilmesini gerektirdi.

Yeni Türkiye Cumhuriyeti'nin 1923-30 yılları arasında radikal bir surette başlattığı siyasi, sosyal ve kültürel Batılılaşma/Avrupalılaşma çabalarına rağmen, tarih anlayışında Avrupamerkezci tarih telakkisine karşı "Türk merkezli tarih"3 inşa etmesini Halil Berktay, "az gelişmiş ülke ve ulusların merkezin tarih ideolojisine karşı çarpıcı ve başarılı bir örnek" olarak değerlendirmektedir (Berktay, 1983, s. 15). 
Yeni Türkiye'nin elitlerinin "günceli Batılılaştııırken tarihi Doğululaştırmaları" bir tür paradoks gibi durmaktadır. Bu durum Bilmez Bülent Can'ın "emperyalizm”, "modernleşme", "uygarlaşma", "gelişme/ilerleme/büyüme/kalkınma" kavramlarına alternatif olarak ileri sürdüğü "standardizasyon" kavramına da uymuyordu (Bilmez, 2000, s. 19). Can;

"Avrupa tarihi üzerine yapılan inceleme ve tartışmalar sonucu ortaya çıkan ... şablon ve onun kriterleri, bir süre sonra Avrupa dışının kültürlerin, tarihinin anlaşııması çabasında da kullanılacaktı. Bu da Avrupa dışının standardizasyonunun, onun "tarihinin standardizasyonu" ile başlatılması demekti."

yorumunu yapıyor (Bilmez, 2000, s. 25). ${ }^{4}$

Hâlbuki1930'da başlayan yeni tarih hareketi, Can'ın vurguladığı "Avrupa standartları"na karşı çıkıyordu. Nitekim; devlet insiyatifi ile yazdırılan Türk Tarihinin Esasları kitabı, tarihte ne yapılmak istendiğini hangi maksatla yazıldığını açıkça ortaya koymaktadır:

"Bu kitap, muayyen bir maksat gözetilerek yazılmıştır.

Şimdiye kadar memleketimizde neşrolunan tarih kitaplarının çoğunda ve onlara mehaz olan Fransızca tarih kitaplarında Türklerin dünya tarihindeki rolleri şuurlu veya şuursuz olarak küçültülmüştür. Türklerin, ecdat hakkında böyle yanlış malumat alması, Türklüğün kendini tanımasında, benliğini inkişaf ettirmesinde zararlı olmuştur. Bu kitapla istihdaf olunan asıl gaye, bugün bütün dünyada tabii mevkiini istirdat eden ve bu şuurla yaşayan milliyetimiz için zararlı olan bu hataların tashihine çalışmaktır, aynı zamanda bu, son büyük hadiselerle ruhunda benlik ve birlik duygusu uyanan Türk milleti için millî bir tarih yazmak ihtiyacı önünde atılmış ilk adımdır. Bununla, milletimizin yaratıcı kabiliyetinin derinliklerine giden yolu açmak, Türk deha ve seciyesinin esrarını meydana çıkarmak, Türkün hususiyet ve kuvvetini kendine göstermek ve millî inkişafımızın derin ırki köklere bağlı olduğunu anlatmak istiyoruz: Bu tecrübe ile muhtaç olduğumuz o büyük millî tarihi yazdığımızı iddia etmiyoruz, yalnız bu hususta çalışacaklara umumi bir istikamet ve hedef gösteriyoruz."

Yine aynı kitapta, Türklerin dünya tarihindeki rolleri hakkında bilhassa Fransızca kitaplar kaynak olarak kullanıldığı, çünkü ülkemizde yayılmış tarih görüşlerinin hemen hepsinin Fransızca kaynaklardan iktibas olduğu için mevcut yanlış telakkilerin de yine Fransız âlimlerinin verdikleri ilmî mütalaalar ve delillerle tashihinin tercih olunduğu özellikle belirtilmektedir (Afet Hf. vd., 1930, s. 1-2). ${ }^{5}$

4 Kitabın girişinde yer alan uzun kavramsal tartışmanın, kitabın isminden dolayı olsa gerek yeteri kadar dikkat çekmediğini düşünüyoruz.

5 Bu eser, Türk Ocağı "Türk Tarihi Heyeti azalarından Afet Hf. ile Mehmet Tevfik, Samih Rifat, Akçura Yusuf, Dr. Reşit Galip, Hasan Cemil, Sadri Maksudi, Şemsettin, Vasıf ve Yusuf Ziya Beyler tarafından iktitaf, tercüme ve telif yollar ile yapılmış bir teşebbüstür. "Türk Tarihi Heyeti"nin başka azalarının ve mevzu ile alakalı zatlerin mütalea ve tenkit nazarlarına arz olunmak üzere yalnız yüz nüsha basılmıştır." (Kitabın kapağından) 
Avrupamerkezci tarihlerde Türklerin bilhassa medeniyete olan katkılarının karartılmasının, Yeni Türkiye elitlerini harekete geçiren husus olduğu açıktır. Nitekim 1930'da yalnız 100 adet yayımlanan Türk Tarihinin Ana Hatları'nın içinde yer alan Methal Kısmı, 1931 yılında Maarif Vekâleti Millî Talim ve Terbiye Dairesi emriyle 30 bin adet çoğaltıııp dağıtılmıştı. Yalnız uzmanların değil, yetişmekte olan Türk gençliğinin de bilmesi istenilen çerçeve şu idi:

"Milattan evvel 9000 yıla varan kadim Türk medeniyetinin bir zaman sonra söndüğünü ve büsbütün tarihe gömüldüğünü tasavvur ve iddia etmek hatadır. Bu medeniyet bir taraftan Çin, Hint, Mezopotamya ve saire gibi yeni intikal mıntıkalarında inkişaf ederken diğer taraftan da asıl kendi sahasında devam ve inkişaf eylemiştir. İklimin müsaadesizleşmesi, hayat şartlarının büyük mikyasta daralması onun ancak hızını durdurmuş ve sahalarını tahdit etmiştir.

Türklerin yalnız harp ile, başkalarının memleketlerini ele geçirmek gaye ve gayretiyle yaşayarak medeniyete hadim olmadıkları yolundaki garazkâr iddia ve iftiraların artık mevsimi geçmiştir. Asırdide Hristiyanlık davalarının doğurduğu bu iptidaî telâkki ve telkinlerle beşeriyetin bir kısmında diğerine karşı kin ve husumet hisleri aşılamanın ne kadar gayriinsani ve gayrimedeni olduğunun anlaşıması zamanları gelmiştir...

Türkler aleyhinde menşei Hristiyanlık taassubu olan ve asırlarca yürütülen garazkâr telkinlerin daima saf ve bitaraf kalması lazımgelen ilmin ruhu içine de sokulmuş olması teessüfe değer hallerdendir...Türkler için menfi diğer bir cereyan iltihak etti. Bütün medeniyetlerin ilk kuruculuğunu Samî ırklara atfetmek gayretinde bulunan bu cereyanın en hararetli körükleyicisî Joseph Halevy ${ }^{6}$ oldu... Arzuya ve temenniye layık olan cihet ilmin kilise kandillerinden, yedi kollu şamdan ışıklarından veya taassup ateşinin alevlerinden değil ancak Hakikatin nurundan aydınlık almasıdır" (Afet Hf. vd., 1930, s. 64-66).

Yeni Laik Türkiye, Avrupamerkezci tarih anlayışı ile Türklüğün tarihteki rolünün göz ardı edilmesini "Hristiyan ve Yahudi" taassubuna bağlıyordu. Burada, "hakikatin nuru" olarak pozitivist bir bilim zihniyetine gönderme yapılıyordu.

6 Joseph Halévy, (1827, Edirne-1917) Osmanlı doğumlu Yahudi-Fransız oryantalist ve seyyah. En önemli çalışmasını, Sabai yazıtlarını bulmak için Yemen'de hazırladı; sonuç olarak 800 yazıtlı değerli bir koleksiyon sundu. Önce doğduğu şehirde sonra da Bükreş'te Yahudi okulunda öğretmenlik yaptı, boş zamanlarında oryantal diller ve arkeoloji çalışıp bu alanda uzmanlaştı. 1868'de, Alliance Israélite Universelle tarafından Habeşistan'a Falaşalarla ilgili bilgi toplaması için gönderildi. Bu göreviyle ilgili sunduğu başarılı rapor, Fransız Enstitüsü (Académie des Inscriptions et Belles-Lettres)'nün ilgisini çekti ve Sabai yazıtlarını çalışması için Yemen'e gönderildi. Halévy, 686 parça yazıt bulup bunIarın şifresini çözdü ve yorumladı; Sabai dili ve mitolojisiyle ilgili eksik bilgileri toplayıp başarılı bir şekilde tekrar yapılandırdı. 1879'da Paris Ecole des Hautes Etudes'de Etiyopyaca üzerine profesör ve Société Asiatique'de kütüphaneci oldu. Halévy'nin geniş anlamda bilimsel çalışmaları, orijinal ve hünerli oryantal filoloji ve arkeoloji eserleri, ona dünya çapında itibar kazandırdı. Asur-Babil yazıtlarında bulduğu Semitik olmayan Sümerce bir deyiş, Asurologlar arasında tartışma konusu oldu. Genel olarak kabul edilen görüşün aksine Halévy, Sümercenin bir dil olmadığı, Semitik Babilliler tarafından kullanılan kavramsal bir yazım metodu olduğu teorisini ortaya attı. Halevy, Paris Üniversitesinde profesördü. bk. (Joseph Halevy, t.y.). 
Türkiye'de 1930 'da hâkim olan bu tarih görüşü, Cumhuriyet'in yeni nesillerine aktarılabilmesi için Türk Tarihi Tetkik Cemiyeti tarafından 4 ayrı tarih kitabı yazıldı ve liselerde okutulmaya başlandı.7 Avrupamerkezci tarih çalışmalarında, Türklerin Moğollar gibi sarı ırktan oldukları ve hiçbir medeniyet yaratmadıkları iddialarına karşı, tarih ders kitaplarında Orta Asya'nın, medeniyetin beşiği olduğu, ilk uygarlık emarelerinin burada yaşayan Türkler tarafından oluşturulduğu, ve iklimde yaşanan değişimler sonucunda dünyanın değişik bölgelerine taşıdıkları ileri sürülmüş; bu prehistorik devirlerde yaşanan göçlerle de Anadolu'nun ilk sakinlerinin Türkler olduğu vurgulanmıştır (Yazıcı, 2011, s. 202).

Tarih çalışmaları hem Türklerin hem de Türkiye'nin tarihine yönelik idi. Çünkü 1930'ların dünyasında hâlen bir ülkenin sahipliğine ilişkin "tarihî haklar" görüşü ağırlıklı olarak kabul görmekteydi. Bu yaklaşım da genç Cumhuriyet'i Anadolu tarihini Türkleştirme gayretine itti. Biz bunu, etki-tepki çerçevesinde değerlendiriyoruz. ${ }^{8}$

Tarih II, III ve IV. kitaplarının başına konan ortak "mukaddime"lerde, Türk Tarihi Tetkik Cemiyetinin neden tarih ders kitapları yazdığı izah edilirken konumuzla ilgili tespitlerde bulunuluyor:

"Son yıllara gelinceye kadar Türk Tarihi memleketimizde en az tetkik edilmiş mevzulardan biri hâlinde idi.

1000 yıldan fazla süren İslamlık-Hıristiyanlık davalarının doğurduğu husumet duygusu ile mutaassıp mürevvihler bu davalarda asırlarca İslamlığın pişdarlığını yapan Türklerin tarihini kan ve ateş maceralarından ibaret göstermeye savaştılar. Türk ve İslam müverrihler de Türklüğü ve Türk medeniyetini İslamlık ve İslam medeniyeti ile kaynaştırdılar; İslamlığa tekaddüm eden binlerce yıla ait devreleri unutturmayı ümmetçilik siyasetinin icabı ve din gayreti vecibesi bildiler. Daha yakın zamanlarda, Osmanlı İmparatorluğu'na dâhil bütün unsurlardan tek bir milliyet yaratmak hayalini güden Osmanlılık cereyanı da, Türk adının anılmaması, millî tarihin yalnız inmal değil, hatta yazıımış olduğu sayfalardan kazınıp silinmesi yolunda üçüncü bir amil hâlinde diğerlerine eklendi.

Bütün bu menfi cereyanlar, tabii olarak, mektep programları ve mektep kitapları üzerinde dahi tesir gösterdi ve Türklüğün, çadır, aşiret, at, silah ve muharebe mefhumlariyle müradif tutulması an'anesi mektep kitaplarımıza kadar girdi." (TTT Cemiyeti, 1933, s. V-VI).

Türk Tarih Tezi, yukarıda işaret edilen yanlışlardan tarihi kurtarmayı hedefliyordu. İslam öncesi Türk tarihi ortaya çıkartılacak vurgulanacak ancak bütün asarı ile hatıraları ile

7 İçeriği hâlen tartışılmakla beraber Türk eğitim tarihinde bu kitaplar kadar kaliteli, özenli tarih ters kitapları basılmamıştır.

8 "Çağdaş Batı'da Anadolu topraklarına daha geç tarihte gelmiş olan Türklerin hiçbir "tarihî hakkı" olmadığı ve Türklerin savaş sanatı dışında bir şey yapmayı beceremedikleri tarzındaki soruları aptalca olarak niteleyen Andrew Mango, aptalca soruların cevaplarının da aptalca olmasının kaçınılmaz olduğunu söylüyordu (Mango, 1999, s. 475). 
canlı bir şekilde yaşanan Osmanlı tarihi göz ardı edecekti. Erol Güngör, "Bu yüzden Türkiye'de milliyetçilik uğruna millî tarih tezine sarılanlar hakikatte bugün (1970'ler) içinde bulunduğumuz millî tarih buhranının temellerini atmış oluyorlardı" diyor (Güngör, 1986, s. 77). ${ }^{9}$

1932 yılına gelindiğinde katılımcıların çoğunu tarih öğretmenlerinin oluşturduğu bir kongre tertip edildi. Maksat tarih dersinin daha verimli nasıl verilebileceği üzerine mütaalada bulunmak idi. Bu, I. Türk Tarih Kongresi açılış konuşmasını yapan devrin Maarif Vekili Esat Bey (1874-1938) ${ }^{10}$, tarihin bir millet hayatında ne kadar önemli olduğunu vurguladıktan sonra;

"Şimdiye kadar okumuş olduğumuz kitaplardan hemen birçoğunun tercüme ve iktibas edilmiş olan asılları ise bu maksada taban tabana zıt olarak hakikatı ve Türk milletinin varlığını ve benliğini ve cihan medeniyetine olan hizmetlerini tebarüz ettirmekten herhangi bir sebeple, uzak bulunmuş idi."

tespitiyle başlıyordu (Maarif Vekaleti \& Türk Tarihi Tetkik Cemiyeti, 1932, s. 5).

I. Türk Tarih Kongresi'nde konuşan Türk Tarihi Tetkik Cemiyeti Başkanı Yusuf Akçura (1876-1935), tarihte Avrupamerkezci yaklaşıma âdeta"meydan okuyarak" tarihe nereden ve hangi noktainazardan baktıklarını anlatıyordu:

"Biz, Avrupa müstemlekeleri hâline getirilen memleketlerin ahalisine müstemlekeci milletler nazarından bakacak değiliz; biz bütün dünyada yaşayan insanları, Avrupalılar gibi ve onlar derecesinde hukuku haiz adam evlatları telakki ediyoruz. Avrupalıları doyurmak ve semirtmek için halk olunmuş bir nevi hayvan sürüleri gibi değil. Buna binaendir ki Avrupalı müelliflerin süsleyip bezeterek medeniyet naşirliği ve insaniyet hadimliği gibi göstermek istedikleri fiil ve hareketlerinin de hakiki mahiyetini görmeye ve göstermeye çalışıyoruz. Müddeamızın (tezimizin) en esaslı vasfı, ayrıcı değil birleştirici, zalim değil adil, düşmanlaştırıcı değil barıştıııcı olmasıdır. Bu cihetle objektif tetkiklere, ilmî terkiplere müstenit müddeamız, manevi, ahlaki noktainazarımızdan da yüksektir...

... Bizim tarihte yapmak istediğimiz şey umumi tarihe Avrupalılar tarafından sokulan kıymetleri tetkik ve tenkit ederek bunlara yeni baştan kıymet biçmektir. Davamız büyüktür. Lakin şimdiye kadar ortaya attığı büyük davaların hepsini kazanan emsalsiz rehberimizin irşatları sayesinde, bu davayı da kazanacağımıza bir an tereddüt etmiyoruz." (Maarif Vekaleti \& Türk Tarihi Tetkik Cemiyeti, 1932, s. 606-607). ilmî çalışmaları neticesinde İslam çağı önem kazanmış ve Türklük ile İslam birbiri ile kaynaştırılmıştır." Tespiti Türk Tarih Tezi'nin etkilerini göstermesi bakımından önemlidir. bk. Kuran, (1994, s. 97).

10 Esat (Sagay) Bey, VI ve VII. Cumhuriyet Hükûmetlerinde Maarif Vekili olarak görev yaptı (27 Eylül 1930-18 Temmuz 1932). Hatıraları yayımlanmıştır: (Sagay, 2012). 


\section{Inkılap, Tarih, Medeniyet ve Meşruiyet}

Tarih düşüncesi üzerine yaptığı çalışmalarla tanınan Ayhan Bıçak, Avrupamerkezci tarih telakkisinin Avrupa dışı toplumların "tarihsiz" olduklarını iddia ettiğini, bir toplumun tarihsiz olmasının anlamının ise Avrupalılar ayarında insan olmamak, özellikle de yabani kabileler insanımsı yaratıklar şeklinde görülmek manasına geldiğini ifade etmektedir. Bıçak; "Bu acımasız yargılardan kurtulmak için Avrupa dışı toplumların tarihçileri modernlik adı altında öğretilen değerlerden hareketle kendi tarihlerini ulusçu bir anlayışla Avrupa tarihine iliştirmeye çalışmıştı."diyor (Bıçak, 2013, s. 54).

Genç Cumhuriyet'in tarih tezinde, öncelikle Avrupa ile "tarihte" hesaplaşma olduğu görülüyor. Hatta bu konuda hiç de mütevazı davranılmıyor. Türk milletinin bütün tarihte var olduğu ve özellikle medeniyet kuruculuğu kuvvetle iddia ediliyor. Bu çabayı "kültürel istiklal harbi" olarak gören ve isimlendirenler olmuştur (Karal, 2001, s. 157). ${ }^{11}$ İkinci olarak ise eski Türk tarihi devirleri anlatılarak yapılan inkılaplara bu devirlerden mehazlar bulunmaya çalışılıyordu. Nitekim Birinci Türk Tarih Kongresi'nin açılışında Maarif Vekili Esat Bey, şöyle konuşuyordu:

“... Cumhuriyet Devri ahlak ve terbiye telakkilerinin ve Cumhuriyet sistemimiz esaslarının derin ve şerefli mazimizden kök ve kuvvet aldığını ve ahlak ve terbiyede millî his, millî ahlak, millî terbiyenin ve Cumhuriyet sistemimizde millî vahdet ve millî hâkimiyetin ve ferdî hak ve hürriyetin esas teşkil eylediğini bu vesile ile tekrarlamak isterim. Bunlar, bizim medeni esaslarla daima tenmiye ve takviye edeceğimiz millî ve tarihî seciyelerimizdir. Türklerde devlet teşkilatının kuvvetli bir merkez hâkimiyeti ile halkçlık esasını telif fikrine istinat ettiğini ve mülkiyet hakkı ile nikâha müstenit aile sisteminin Türklerde tarihten evvelki devirlerde teessüs etmiş olduğunu tarihin birinci kitabında ve Türklerin millî ve tarihî seciyeleri arasında okuyoruz. Millî terbiyemizde esas olan milliyetçilik, devletçilik, halkçılık, işte hep bu millî ve tarihî seciyemizden doğmuştur." (Maarif Vekaleti \& Türk Tarihi Tetkik Cemiyeti, 1932, s. 13).

Büşra Ersanlı Behar, Türk Tarih Tezi'ne getirmiş olduğu eleştiriler içerisinde şunu da eklemektedir:" Osmanlı ve İslam dönemlerini âdeta inkâr ederek romantik bir İslam ve tarih öncesi anlayışının laikliği ile bir altın çağ yaratmaya uğraşmıştır." (Ersanlı Behar, 1992, s. 197). Türk Tarih Tezi, yeni laik rejimin önceliklerini dikkate alarak tarihi araç olarak ele almış ve Türk tarihini dinden arındırılarak laikleştirilmiştir. ${ }^{12}$ Laikliği de tarihteki Türk devletlerinin laik olduğu iddiasıyla meşrulaştırmaya çalışmıştır. ${ }^{13}$

11 II. Türk Tarih Kongresi'nde tanınmış Avusturyalı bilgin Menghin, “Türklerin cihan tarihindeki hissesi sınırlandırılamaz. Türk tarihinin cihan tarihini büyük gelişime götüren bir kuvvet olduğuna şüphe yoktur." demesini büyük tarihçimiz Halil İnalcık, "Atatürk için bu netice, kazanılmış bir meydan muharebesi kadar değerli idi." diye yorumlamaktadır. bk. İnalcık, (2009, s. 140).

12 "Yusuf Akçura'nın laik tarih anlayışı Atatürk için aydınlatıcı olmuştur." bk. Kuran (1994, s.213).

13 Bu noktada şu bilgi de ilginçtir; Osmanlı Devleti'nde ilk Türkçü eserlerden sayılan Polonya mültecilerinden Mustafa Celaleddin Paşa'nın, yazmış olduğu (1869), Les Turcs: anciens et modernes (Eski ve 
Türk Tarih Tezi, Doğu ve Batı medeniyeti tanımı yapmıyor. Kadim bir Türk medeniyeti anlatısı var; fakat bunun tarih öncesi devirlerde bütün dünyaya dağılarak Avrupa'dan Çin'e hemen bütün insan topluluklarının medenileşmesine katkıda bulunduğu anlatılıyordu. Böylece Cumhuriyet'in 1920'lerde radikal Batılılaşmaya getirilen ve getirilecek olan eleştirilere kökten bir çözüm sunulmuş oluyordu: Yani Batı medeniyeti de Türklerin önemli ve anlamlı etki ettiği, katkı verdiği bir medeniyettir. Dolayısıyla onu almakta, kabul etmekte bir mahsur yoktur algısı yaratılmak isteniyordu.

Nitekim Mustafa Kemal Paşa'nın medeniyete bakışı da daha 1923 yılında tam böyledir:

"Memleketler muhteliftir; fakat medeniyet birdir ve bir milletin gelişmesi için de bu yegâne medeniyete iştirak etmesi lazımdır." (Akt., Kocatürk, 1999, s. 68). ${ }^{14}$

1930'a geldiğimiz zaman ise Mustafa Kemal Paşa, kadim ve çağdaş medeniyet arasında bir irtibatı bizzat kendisi kurmuştur: "Muasır medeniyet'i anlayabilmek, kavrayabilmek, kadim medeniyeti dünya yüzünde, bütün beşeriyetin, ilk medeniyetleri doğru tanıyabilmekle mümkündür." (Genelkurmay Başkanlığı, 2001, s. 356) Tarık Zafer Tunaya (19161991), "Türk devrimcilerine göre Batı hâkim medeniyettir, müşterek medeniyet olmalıdır. Uygarlık hepimizindir." anlayışına sahip olduklarını tespit ediyordu (Tunaya, 1967, s. 41-45). ${ }^{15}$

Bitirirken Türk tarih tezi, millî, Millî bir tarih inşa etme gayesindedir. Yalnız, millî değerler ve Türklük, modern ve laik bir şekil ve içerikte tanımlanmıştır. Türk tarih tezi, Avrupamerkezli tarih yaklaşımlarına bir tepki olarak ortaya çıkmıştır, ancak, muasır medeniyetin inşasında Türklerin de katkı sahibi olduklarını ileri sürmüştür. Böylelikle Türk tarih tezi, çağdaş Batı/Avrupa medeniyetine bir alternatif ortaya koyma iddiası taşımamaktadır. Aksine, çağdaş Batı medeniyeti dünyanın ortak medeniyeti olarak

Yeni Türkler) kitabında Batı uygarlığını yaratmış kavimlerle Türkler arasında kökende bir dil ve ırk birliğinin bulunduğunu öne sürerek Türklere yeni bir tarihî amaç (=Batılılaşma) kazandırmak istemesi nedeniyle bazı yazarlarca Atatürk'ün tarih tezinin ilk habercisi sayılmaktadır. (Akt. Berktay, 1983, s. 29)

14 Andrew Mango da Atatürk'ün "tek çağdaş medeniyet" fikrinde olduğuna işaret etmektedir. (Mango, 1999, s. 475).

15 Afet İnan'ın da benzer görüşleri için bk. İnan, (1977, s. 194). Halil İnalcık ise "Atatürk inanıyordu ki modern millet kavramı bugün cihanşümul medeniyetin temel taşıdır ve insanlık cihanşümul bir medeniyete sahip milletlerin ahenkli bir topluluğu olmaya doğru gitmektedir. Atatürk bu yüksek insanlık idealini tam bir açıklıkla ifade etmiştir: 'Beşeriyetin hepsini bir vücut ve bir milleti, bunun bir uzvu addetmek icap eder.' 'lç̧inde bulunduğumuz aile-i medeniyette layık olduğumuz mevkii bulacak ve onu muhafaza ve i'lâ edeceğiz." bk. İnalcık, (2009, s. 145). Nitekim İbrahim Bahadır, Türk Tarih Tezi'ni Türkiye'nin o günkü ihtiyacına göre düzenlenmiş bir çalışma olarak görmek gerektiğini vurgular ve her ne kadar Atatürk dillendirmese de onun çok yakınında bulunan ve onu destekleyen Yakup Kadri, Enver Ziya Karal, bu tezin bilimsel olmaktan çok siyasal bir işlev gördüğünü itiraf ettiklerini söylemektedir. bk. Bahadır, (2001, s. 200).

Ancak, bugün hem bizde hem de dünyada tek bir medeniyet algı ve anlayışından uzaklaşılmıştır. Nitekim Türkiye ve İspanya öncülüğünde başlatılan Medeniyetler İttifakı projesi Birleşmiş Milletlerce tanınmış ve 2005 yılında BM Genel Sekreteri Kofi Annan tarafından Medeniyetler İttifakı Yüksek Düzeyli Grubu oluşturulmuştur, bu grup, hâlen çalışmalarına devam etmektedir. 
kabul edilmekte ve Yeni Türklerin de bu medeniyeti benimsemeleri arzu edilmektedir. Dolaylı bir şekilde Cumhuriyet Dönemi radikal Batılılaşma hareketi meşrulaştırılmış olmaktadır. Türk Tarih Tezi, Türklere bir tarih inşa ederken alternatif medeniyet kurma iddialarından da vazgeçtiklerini ilan etmektedir. Geçmişin Doğululaştırılması, güncelin Batılılaştırılmasına engel teşkil etmemektedir. Ayrıca Türk Tarihini Tetkik Cemiyeti Başkanı Yusuf Akçura'nın da açıkça söylediği üzere Türk tarih tezinin dünyanın hiçbir milletine karşı düşmanca bir yanı ve irredantist bir yönü de bulunmamaktadır. Ama Akçura'nın söylemediği yanı Türk tarih tezi'nin çağdaş Türkiye'ye ve dünyaya alternatif bir "Türk Medeniyeti Tezi" de teklif etmediğidir.

\section{Kaynakça}

Afet Hf., Tevfik, M., Rifat, S., Yusuf, A., Galip, R. Cemil, H. vd. (1930). Türk tarihinin ana hatları. İstanbul: Devlet Matbaası.

Bahadır, I. (2001). Ümmetten millete Türk ulusunun inşası (1860-1945). Ankara: Kalan Yayınevi.

Blaut, J. M. (2012). Sömürgeciliğin dünya modeli coğrafi yayılmacılık ve Avrupamerkezci tarih (Çev. B. Serbun). İstanbul: Dergâh Yayınevi.

Beritan, F. \& Şimşek, A. (2011). Tarih yazımında Avrupamerkezciliğin izleri. V. Engin \& A. Şimşek (Ed.), Türkiye'de tarih yazımı içinde (s. 301-314). İstanbul: Yeditepe Yayınları.

Berktay, H. (1983). Cumhuriyet ideolojisi ve Fuat Köprülü. İstanbul: Kaynak Yayınları.

Berktay, H. (2002). Türklerin tarihinde temel yanlışlar. (Ed.Sina Akşin), Türkiye tarihi I içinde s. 36-66. Istanbul, Cem Yayınevi.

Bıçak, A. (Bahar, 2013). Tarih düşüncesi. Cogito, 73, s.36-60.

Can, B. Bülent, (2000). Demiryolundan petrole Chester Projesi (1908-1923). Istanbul: Tarih Vakfı Yurt Yayınları.

Çırakman, A. (Şubat-Mart-Nisan, 2001). Avrupa fikrinden Avrupamerkezciliğe. Doğu Batı, 14, $28-52$.

Ersanlı Behar, B. (1992). iktidar ve tarih Türkiye'de resmî tarih tezinin oluşumu (1929-1937). İstanbul: Iletişim Yayınları.

Genelkurmay Başkanlığı. (2001). Atatürkçülük I. İstanbul: Millî Eğitim Bakanlığı.

Goody, J. (2012). Tarih hırsızığı (Çev. G. Çağalı Güven). İstanbul: İş Bankası Kültür Yayınları.

Güngör, E. (1986). Kültür değişmesi ve milliyetçilik. İstanbul: Ötüken Neşriyat.

Iggers, G. (2003). 20. Yüzyılda Tarih Yazımı. Tarihin Kötüye Kullanımı içinde (s. 3-13) (Çev. Nurettin Elhüseyni). İstanbul: Tarih Vakfı Yayınları.

İnalcık, H. (2009). Atatürk ve demokratik Türkiye. İstanbul: Kırmızı Yayıncılık.

Inan, A. (1977). Türkiye Cumhuriyeti ve Türk devrimi. Ankara: Türk Tarih Kurumu Yayınları.

Joseph Halevy. (t.y.). 1 Eylül 2013 tarihinde http://tr.wikipedia.org/wiki/Joseph_Hal\%C3\%A9vy adresinden edinilmiştir.

Karal, E. Z. (2001). Atatürk'ün Türk tarih tezi. Atatürkçülük /l içinde (s. 157-164). İstanbul: Millî Eğitim Bakanlığı Yayınları.

Kocatürk, U. (1999). Atatürk'ün fikir ve düşünceleri. Ankara: Atatürk Araştırma Merkezi Yayınları. 1 Eylül 2013 tarihinde http://atam.gov.tr/ataturkun-fikir-ve-dusunceleri-2/ adresinden edinilmiştir. 
İnsan \& Toplum

Kuran, E. (1994). Türkiye'nin Batılılaşması ve millî meseleler. Ankara: Diyanet Vakfı Yayınları.

Maarif Vekaleti \& Türk Tarihi Tetkik Cemiyeti. (1932). Birinci Türk Tarih Kongresi konferanslar ve müzakere zabıtları. İstanbul: Türk Tarih Tetkik Cemiyeti Yayınları.

Mango, A. (1999). Atatürk (Çev. F. Doruker). İstanbul: Remzi Kitapevi.

Ponting, C. (2012). Yeni bir bakış açısıyla dünya tarihi (Çev. E. B. Özbilen). İstanbul: Alfa Basım Yayın Dağıtım.

Sagay, E. (2012). Hocam: Maarif Vekili Esat Sagay'ın hatıraları (Hzl. E. Sagay). İstanbul: Yapı Kredi Yayınları. Şimşek, A. (Nisan, 2007). Türkiye'de tarih eğitiminin ulusallığı ve Avrupamerkezcilik. Türkiye Sosyal Araştırmalar Dergisi, 1, 16-17.

TTT Cemiyeti. (1933). Tarih II. İstanbul: Türk Tarih Tetkik Cemiyeti Yayınları.

Tunaya, T. Z. (1967). Atatürk ve medeniyetçilik. Büyük Atatürk içinde (s. 41-45). İstanbul: Nebioğlu Yayınları.

Yazıcı, F. (2011). Cumhuriyet Dönemi tarih ders kitaplarında tarihyazımı. V. Engin \& A. Şimşek (Ed.), Türkiye'de tarih yazımı içinde (s. 197-219). İstanbul: Yeditepe Yayınları. 